\title{
Pengaruh Alat Permainan Edukatif (APE) Lempar Bola Terhadap Perkembangan Fisik Motorik Kasar Anak Kelompok B di RA Siti Aisyah Pajaran Rembang Pasuruan
}

\author{
Siti Sakdiyatul Uyun ${ }^{1,}$ Yuli Ani Setyo Dewi ${ }^{2}$ \\ ${ }^{12}$ STITNU Al Hikmah Mojokerto \\ darmawanhafidz16@gmail.com \\ yulianisetyo85@gmail.com
}

\begin{abstract}
Abstrak: Tujuan yang ingin dicapai dalam penelitian ini adalah untuk meningkatkankan kemampuan motorik kasar kelompok B RA Siti Aisyah Pajaran rembang Pasuruan. Penelitian ini merupakan Penelitian Tindakan Kelas (PTK) atau Classroom Action Research (CAR). Kemmis \& McTaggart (Suwarsih Madya 2011: 9) menyatakan bahwa penelitian tindakan kelas merupakan suatu bentuk penelitian refleksif diri kolektif yang dilakukan oleh para guru dalam sebuah situasi untuk meningkatkan penalaran dan keadilan praktik pendidikan dan praktik sosial, serta pemahaman terhadap praktik dan terhadap situasi di tempat praktik yang dilakukan. Dalam Penelitian ini subjek penelitian adalah kelompok B RA Siti Aisyah Pajaran rembang Pasuruan tahun pelajaran 2017/2018 yang berjumlah 17 orang. Terdiri dari siswa putra 6 dan siswa putri 11. Dalam penelitian ini yang digunakan adalah bentuk check list. Dari data yang diperoleh peneliti dapat disimpulkan bahwa kegiatan bermain lempar tangkap bola besar pada siklus I telah meningkatkan motorik kasar khusunya pada aspek keseimbangan, kekuatan dan kelentukan. Peningkatan pada siklus I rata-rata belum mencapai indikator keberhasilan, dan pada siklus ke II indikator keberhasilan telah tercapai dengan baik. Melalui keberhasilan tindakan yang telah diberikan diharapkan dapat membantu guru untuk menerapkan kegiatan bermain lempar tangkap bola untuk meningkatkan motorik kasar anak sehingga anak dapat mencapai kemampuan motorik dengan baik. Melalui data yang disajikan terlihat jelas bahwa terdapat peningkatan yang signifikan pada setiap tahapannya. Pada siklus II penelitian dihentikan karena pada tahap tersebut masing-masing anak sudah mencapai indikator keberhasilan yaitu $75 \%$.
\end{abstract}

Kata Kunci : Lempar Bola, Fisik Motorik Kasar 


\section{PENDAHULUAN}

Anak Usia Dini adalah anak yang berada pada usia 0-8 tahun menurut National association for the education young children, (Takdirotun Musfiroh 2008: 1). Pada masa kanak-kanak dunia anak identik dengan keceriaan, kesenangan dan kegembiraan, sering kita dengar bahwa pada masa ini anak mengalami masa golden age atau masa keemasan dimana $80 \%$ dari otak anak sudah bekerja yang ditandai dengan perubahan pada prekembangan anak secara cepat baik fisik, kognitif, sosial emosional, nilai moral agama, bahasa. Anak-anak tidak bisa lepas dari aktifitas-aktifitas yang membuat dirinya bisa merasakan dirinya senang, mereka bisa meluapkan keceriaan, kegembiraan dan senang melalui bermain, karena dunia anak memang dunia bermain. Padahal sejatinya anak usia dini diberikan waktu yang banyak untuk bermain, karena dunia anak adalah dunia bermain sambil belajar. Pendidikan yang diberikan kepada anak sejak dini tidak seperti pendidikan yang sangat formal seperti yang orang dewasa lakukan, harus berangkat kesekolah dengan seragam, belajar secara serius, dan menaati aturan. Pembelajaran pada anak usia dini lebih menekankan pada pembiasaan pada anak dan aspek-aspek perkembangan pada anak itu sendiri. Dari hasil penelitian yang telah dilakukan (Dewi, 2017) banyak stimulasi yang digunakan oleh para guru agar perkembangan bahasa siswanya bisa berkembang secara maksimal yaitu diantaranya mengajak mereka berdialog dan berkomunikasi baik di dalam maupun di luar kelas.

Pendidikan anak usia dini (PAUD) merupakan pendidikan yang diberikan kepada anak usia 0-8 tahun. Anak usia dini dipandang memiliki sebuah kreatifitas yang 
berbeda dibandingkan dengan usia-usia yang ada setelah usia tersebut. Anak adalah generasi penerus bangsa yang kelak membangun bangsa indonesia menjadi bangsa yang maju, maka Pendidikan Anak Usia Dini sangat penting bagi keluarga untuk menciptakan generasi sumber daya manusia yang lebih baik. Hasil dari penelitian yang dilakukan oleh (Dewi, 2014) menunjukkann bahwa salah satu penghambat guru dalam pembelajaran adalah kurangnya media pembelajaran yang dimiliki oleh sekolah.

Perkembangan motorik merupakan perkembangan gerakan jasmani yang melalui kegiatan pada pusat syaraf, dan otot yang terkoordinasi Hurlock (1978: 150). Pada pembelajaran anak usia dini, materi yang diajarkan guru kepada siswa harus sesuai dengan kurikulum yang ada dikarenakan ketidak sesuaian materi dengan kurikulum yang ada dapat memberikan pengaruh adanya ketidak optimalan suatu tujuan pembelajaran. Seperti yang di ketahui bahwa tangan memiliki peranan penting bagi manusia, apabila tangan tidak dilatih secara baik bisa saja tangan menjadi kaku dan tidak tumbuh secara optimal jika tidak ada latihan.Hurlock (1978: 151) berbagai kegiatan motorik yang menggunakan tangan, pergelangan tangan dan jari tangan merupakan perkembangan yang dapat diprediksikan.

Rumusan Masalah Berdasarkan latar belakang, identifikasi dan pembatasan masalah maka rumusan masalah yang akan di ajukan adalah bagaimana bermain lempar tangkap bola dapat meningkatkan kemampuan motorik kasar anak kelompok B di RA Siti Aisyah Pajaran rembang Pasuruan? 
Tujuan Penelitian yang ingin dicapai dalam penelitian ini adalah untuk meningkatkankan kemampuan motorik kasar kelompok B RA Siti Aisyah Pajaran rembang Pasuruan.

Manfaat Penelitian Dengan mengetahui peningkatan kemampuan motorik kasar melalui bermain lempar tangkap bola belajar pada kelompok B RA Siti Aisyah Pajaran rembang Pasuruan .akan memberi manfaat:

1) Manfaat yang bersifat teoritis

Hasil penelitian dapat menambah pengetahuan mengenai motorik kasar anak dan tentang peningkatan kemampuan motorik kasar anak melalui metode bermain.

2) Manfaat yang bersifat praktis

Hasil penelitian ini dapat memberikan informasi tentang peningkatan kemampuan motorik kasar anak melalui bermain lempar tangkap.

a) Bagi anak

Memberikan pengalaman, pengetahuan baru pada anak dalam meningkatkan keterampilan mengasah motorik kasar melalui bermain lempar tangkap.

b) Bagi guru

Sebagai sarana untuk mengevaluasi keberhasilan dalam tugasnya sehingga guru akan selalu memperhatikan motorik kasar anak. 
c) Bagi sekolah

Sebagai bahan masukan dalam pertimbangan serta masukan untuk menentukan kebijakan dan program dalam upaya meningkatkan kualitas perkembangan fisik pada kelompok B.

\section{METODE PENELITIAN}

Penelitian ini merupakan Penelitian Tindakan Kelas (PTK) atau Classroom Action Research (CAR). Kemmis \& McTaggart (Suwarsih Madya 2011: 9) menyatakan bahwa penelitian tindakan kelas merupakan suatu bentuk penelitian refleksif diri kolektif yang dilakukan oleh para guru dalam sebuah situasi untuk meningkatkan penalaran dan keadilan praktik pendidikan dan praktik sosial, serta pemahaman terhadap praktik dan terhadap situasi di tempat praktik yang dilakukan.

Desain Penelitian Penelitian Tindakan kelas yang digunakan dalam penelitian ini adalah penelitian mengacu pada model Suharsimi Arikunto. Adapun desain penelitian yang dilakukan merupakan desain penelitian tindakan kelas. Model atau desain penelitian Suharsimi Arikunto (2010: 16) berupa bagan yang digambarkan sebagai berikut:

Empat langkah utama dalam penelitian tindakan kelas, dari setiap siklus terdiri dari 4 tahapan, tahapan tersebut adalah sebagai berikut:

1) Perencanaan

2) Pelaksanaan

3) Pengamatan 


\section{4) Refleksi}

Tempat penelitian adalah tempat yang digunakan dalam penelitian untuk memperoleh data yang diinginkan. Penelitian ini bertempat di RA Siti Aisyah Pajaran Kec.Rembang Kab. Pasuruan Jatim. Waktu Penelitian Waktu penelitian adalah waktu berlangsungnya penelitian atau saat penelitian dilangsungkan. Penelitian dilaksanakan pada bulan Oktober di semester Ganjil tahun pelajaran 2017/2018. Subjek Penelitian Suharsimi Arikunto (2010: 99) mengemukakan bahwa subjek penelitian adalah benda, hal atau orang tempat variabel melekat. Dalam Penelitian ini subjek penelitian adalah kelompok B RA Siti Aisyah Pajaran rembang Pasuruan tahun pelajaran 2017/2018 yang berjumlah 17 orang. Terdiri dari siswa putra 6 dan siswa putri 11.

Metode Pengumpulan data Dalam penelitian ini metode pengumpulan data yang digunakan adalah sebagai berikut:

1. Observasi digunakan untuk mengamati tingkat kemampuan motorik kasar anak. Wina Sanjaya (2009: 86) menyatakan observasi merupakan teknik mengumpulkan data yang dilakukan dengan cara mengamati kejadian yang berlangsung dan mencatatnya dengan alat observasi tentang hal yang akan diamati dan diteliti. Observasi sendiri dilakukan sebagai alat pantau guru untuk memantau siswa.

2. Dokumentasi digunakan untuk memperkuat data yang diperoleh melalui observasi. Dokumentasi yang digunakan oleh peneliti dalam penelitian ini adalah dengan mengambil gambar anak pada saat anak sedang dalam 
proses pembelajaran. Gambar berupa foto yang dapat menggambarkan keadaan nyata yang terjadi pada saat anak melakukan aktifitas pada pembelajaran motorik.

Instrumen Penelitian Dalam penelitian ini yang digunakan adalah bentuk check list. Wina Sanjaya (2009: 93) Check list merupakan daftar pedoman observasi yang akan digunakan oleh peneliti untuk mengamati aspek apa saja yang akan diobservasi, berisikan daftar aspek yang akan diobservasi, sehingga tugas sebagai observer tinggal memberi tanda $(\sqrt{ })$ pada bagian yang diobservasi. 
Teknik analisis data yang digunakan dalam penelitian ini adalah analisis deskriptif kuantitatif dan kualitatif. Deskripsi kuantitatif digunakan untuk menganalisis data berupa angka. Deskriptif kualitatif dimaksudkan untuk menggambarkan hasil pengamatan peneliti dan kolaborasi dengan guru kelas tentang kemampuan keseimbangan, kekuatan dan kelentukan bertujuan untuk mengetahui peningkatan kemampuan motorik kasar anak melalui bermain lempar tangkap bola besar. Acep Yoni (2010: 177) data yang berhasil dikumpulkan oleh peneliti dikumpulkan dianalisis untuk mengetahui target pencapaian pembelajaran dengan menggunakan rumus :

Prosentase $=\frac{\text { slcor yang diperoleh }}{\text { skor maksimal ideal }} \times 100 \%$

Indikator keberhasilan tindakan dalam penelitian ini akan dikatakan berhasil jika kemampuan motorik kasar anak mengalami peningkatan sebesar 75\% dari jumlah anak kelompok B RA Siti Aisyah.

\section{HASIL PENELITIAN}

Lokasi penelitian ini berada di RA Siti Aisyah yang beralamatkan di Pajaran, Kecamatan Rembang, Kbupaten Pasuruan. Penelitian ini dilaksanakan pada semester I tahun ajaran 2017/2018. RA ini terletak di pedesaan dengan medan pegunungan, TK ini sempat menjadi salah satu RA yang masuk kedalam kriteria 
sekolah terpencil. Mayoritas penduduk berprofesi sebagai buruh dan petani. RA Siti Aisyah memiliki satu ruang kelas utama, ruang guru, dan ruang toilet.

Tenaga pengajar yang dimiliki oleh RA Siti Aisyah berjumlah 4 orang pengajar, pengajar utama adalah kepala sekolah yang juga merangkap sebagai guru, tiga guru sentra disekolah. Sedangkan jumlah siswa yang ada di RA Siti Aisyah berjumlah 17 anak, 11 siswa perempuan dan 6 siswa laki-laki.

Kondisi awal anak sebelum tindakan peneliti melakukan kegiatan yang dilakukan sebelum melakukan penelitian tindakan dan sebagai awalan yang dilakukan sebelum penelitian bertujuan untuk mengetahui kondisi awal anak sebelum melakukan tindakan. Pengamatan yang dilakukan oleh peneliti dilakukan melalui observasi. Peneliti akan meningkatkan motorik kasar anak pada kelompok B dengan melakukan kegiatan bermain lempar tangkap bola besar, dimana siswa kelompok B akan dijadikan subyek penelitian sebanyak 17 anak. Kegiatan pengamatan dilaksanakan pada saat kegiatan awal. Kegiatan pembelajaran yang sebelumnya diberikan pada anak kurang memaksimalkan kemampuan motorik kasar pada anak. adapun masalah yang peneliti temukan sebagai berikut:

(1) Sebagian besar anak kurang motivasi baik secara intern maupun ekstern, (2) Anak kurang percaya diri terhadap kemampuan diri sendiri.

Pelaksanaan Penelitian Siklus I Pelaksanaan tindakan pada siklus I ini dilakukan sebanyak 3 kali pertemuan. Pelaksanaan penelitian dilakukan pada kegiatan awal, penelitian ini dilakukan kurang lebih 30 menit.

Perencanaan Tahapan dalam siklus I meliputi kegiatan sebagai berikut:

1) Menentukan tema pembelajaran. 
2) Merencanakan Pelaksanaan Pembelajaran yang dicantumkan dalam Rencana Pembelajaran Harian (RPPH).

3) Mempersiapkan Instrumen Penelitian

4) Menyiapkan media yang akan digunakan

5) Mempersiapkan alat untuk mendokumentasikan kegiatan pembelajaran yang dilakukan berupa foto.

Pelaksanaan Tindakan Pertemuan ke 1 Pertemuan pertama dilaksanakan pada hari Senin, 04 September 2017 yang dimulai pada pukul 07.30 WIB. Pada pertemuan yang pertama tema yang disampaikan adalah Air, Udara, Api dengan sub tema Api. Jumlah anak yang mengikuti pembelajaran pada siklus I pertemuan I sebanyak 17 anak.
a) Persiapan
b) Pendahuluan
c) Kegiatan Inti
d) Kegiatan Akhir

Pertemuan ke 2 siklus I dilaksanakan pada hari Selasa, 05 September 2017 dari pukul 07.30 WIB. Dengan tema dengan Air, Udara, Api dengan sub tema Api. Jumlah anak yang mengikuti pembelajaran pada siklus I pertemuan 2 sebanyak 17 anak. Berikut gambaran penelitian tindakan kelas yang telah dilaksanakan.

a) Persiapan 
b) Pendahuluan

c) Kegiatan Inti

d) Kegiatan Akhir

Pertemuan ke 3 siklus I dilaksanakan pada hari Rabu,06 September 2017 dari pukul 07.30 WIB. Dengan tema dengan Air, Udara, Api dengan sub tema Api. Jumlah anak yang mengikuti pembelajaran pada siklus I pertemuan 2 sebanyak 17 anak.
a) Persiapan
b) Pendahuluan
c) Kegiatan Inti
d) Kegiatan Akhir

Observasi Dalam kegiatan observasi yang diamati adalah seluruh kegiatan anak selama mengikuti aktivitas bermain lempar tangkap bola besar. Pengamatan dilaksanakan dalam pendampingan dalam pembelajaran. Selama proses pembelajaran siklus I selama 3 pertemuan berjalan dengan lancar mulai dari kegiatan awal sampai dengan kegiatan akhir sesuai dengan yang direncanakan. Setelah diberi penjelasan dan gambaran, anak melakukan kegiatan bermain lempar tangkap bola. Hari pertama dilakukan tindakan anak kelihatan masih kebingungan bagaimana cara melakukan kegiatan melempar dan menangkap bola, bahkan ada anak yang benarbenar tidak ingin melakukan kegiatan, tetapi guru terus memberikan motivasi pada anak dan memberikan bimbingan kepada anak bagaimana caranya anak mau untuk melakukan kegiatan. Hal yang diamati disesuaikan dengan instrumen yaitu: kekuatan, keseimbangan, kelentukan.

Refleksi Kegiatan refleksi ini dimaksudkan sebagai bahan masukan pada perencanaan yang akan dilaksanakan pada siklus yang selanjutnya. Kendala yang 
muncul yang dapat mempengaruhi ketercapaian motorik kasar dengan seoptimal mungkin. Adapun beberapa kendala yang perlu di cari solusinya:

1) Anak terlalu terburu-buru dalam melakuakan kegiatan

2) Anak cenderung kurang menghargai kemampuan teman

3) Kurangnya motivasi dari diri anak

Dari kendala yang ada peneliti dan kolaborator berdiskusi untuk mencari solusi dari kendala yang ada. Solusi dari beberapa kendala tersebut antara lain:

1) Anak diberikan peringatan dan diberikan pengawasan.

2) Sebelum anak melakukan kegiatan melempar dan menangkap guru memberikan aba-aba terlebih dahulu.

3) Anak diberi penjelasan mengenai menghargai orang lain.

4) Guru dan teman memberikan motivasi sebelum anak melakukan kegiatan melempar dan menangkap

5) Anak diberikan kesempatan untuk tampil satu persatu.

Pelaksanaan Penelitian Siklus II Berdasarkan refleksi pada Siklus I maka penelitian dilanjutkan masuk pada Siklus II. Oleh karena itu, hipotesis pada Siklus II adalah melalui bermain lempar tangkap bola, dengan cara memberikan kesempatan satu per satu anak melakukan kegiatan, dan memberikan reward dapat meningkatkan kemampuan motorik kasar dengan anak RA kelompok B. 
Perencanaan Berikut susunan perencanaan meliputi:

1) Menentukan tema pembelajaran

2) Menyusun rencana kegiatan pembelajaran

3) Mempersiapkan instrumen penelitian

4) Menyiapkan media yang akan digunakan

5) Mempersiapkan alat untuk mendokumentasikan kegiatan pembelajaran yang dilakukan berupa foto.

Pelaksanaan Tindakan Pertemuan ke 1 Pelaksanaan siklus II pertemuan 1 ini dilaksanakan pada hari Senin, 11 September 2017. Dengan tema Air, Udara, Api dengan sub tema Air. Jumlah anak yang mengikuti pembelajaran pada siklus I pertemuan 2 sebanyak 17 anak. Berikut gambaran penelitian tindakan kelas yang telah dilaksanakan. Kegiatan-kegiatan yang dilakukan adalah sebagai berikut:
a) Persiapan
b) Pendahuluan
c) Kegiatan Inti
d) Kegiatan Akhir

Pertemuan ke 2 Pelaksanaan siklus II pertemuan 2 ini dilaksanakan pada hari Selasa 12 September 2017. Dengan tema Air, Udara, Api dengan sub tema Air. Jumlah anak yang mengikuti pembelajaran pada siklus I pertemuan 2 sebanyak 17 anak. Berikut gambaran penelitian tindakan kelas yang telah dilaksanakan.
a) Persiapan
b) Pendahuluan 
c) Kegiatan Inti

Anak diberi kesempatan satu per satu melempar dan menangkap bola kepada teman pasangannya. Pada siklus II pertemuan II hampir semua anak sudah bisa melakukan gerakan melempar dan menangkap dengan seimbang, kuat dan lentuk, anak hanya tinggal berusaha mempertahankan apa yang sudah di tingkatkan.

d) Kegiatan Akhir

Pertemuan ke 3 Pelaksanaan siklus II pertemuan 3 ini dilaksanakan pada hari Rabu 13 September 2017. Dengan tema Air, Udara, Api dengan sub tema Air. Jumlah anak yang mengikuti pembelajaran pada siklus I pertemuan 2 sebanyak 17 anak. Berikut gambaran penelitian tindakan kelas yang telah dilaksanakan.
a) Persiapan
b) Pendahuluan
c) Kegiatan Inti
d) Kegiatan Akhir .
e) Observasi

\section{PEMBAHASAN}

Pembelajaran pada siklus I dan siklus II yang telah dilakukan dan dilaksanakan pembelajarannya telah direfleksi, peningkatan kemampuan motorik kasar melalui bermain lempar tangkap bola besar berimplikasi baik pada peningkatan kemampuan motorik khususnya pada keseimbangan, kekuatan, kelentukan motorik kasar kelompok B RA Siti Aisyah Pajaran, Rembang, Pasuruan. Hal tersebut dapat dibuktikan dengan data yang diperoleh peneliti telah menunjukkkan peningkatan setelah proses pembelajaran. 
peningkatan motorik kasar anak dari masing-masing siklus tersebut dapat disajikan pada grafik sebagai berikut:

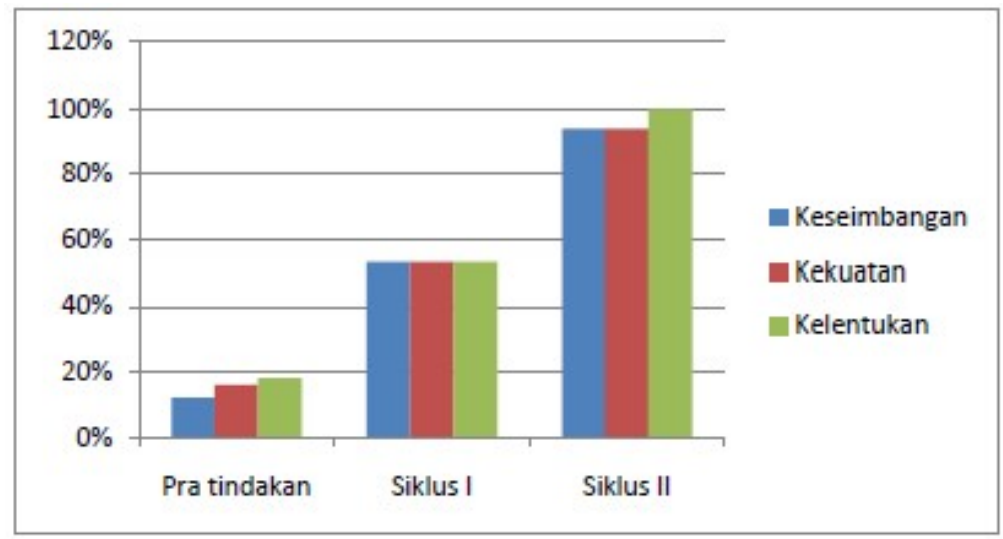

Gambar 1. Grafik Perbandingan Kemampuan Motorik Kasar Anak

Peningkatan kemampuan motorik kasar anak juga dilihat dari grafik peningkatan motorik kasar anak :

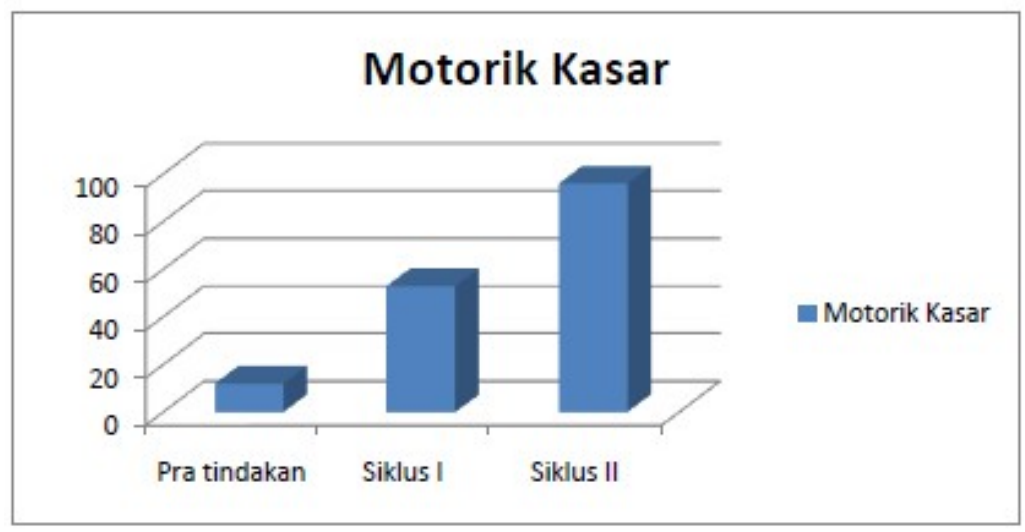

Gambar 2. Grafik Rekapitulasi Hasil Kemampuan Motorik Kasar Anak 


\section{KESIMPULAN}

Peningkatan kemampuan motorik kasar tersebut dapat dikatakan optimal dilihat berdasarkan dari hasil data observsai dan dokumentasi yang diperoleh pada setiap siklusnya. Dapat dilihat bahwa kondisi awal anak sebelum adanya tindakan menunjukkan kemampuan motorik kasar pada anak menunjukkan bahwa 2 (12\%) anak mampu melakukan kegiatan melempar dan menangkap dengan seimbang, 1 (6\%) anak mampu melempar dan menangkap dengan seimbang dan $3(18 \%)$ anak mampu melempar dan menangkap dengan lentuk. Setelah melakukan pratindakan dilakukan tindakan pada siklus I dan siklus II yang mengalami peningkatan. Pada kemampuan motorik keseimbangan siklus I 9 (53\%) anak mampu melempar dan menangkap dengan seimbang pada siklus II meningkat menjadi 16 (94\%) anak mampu seimbang melempar dan menangkap bola. Pada kemampuan motorik kekuatan 9 (53\%) anak mampu melempar dan menangkap dengan kuat, pada siklus II meningkat menjadi 16 (94\%) anak mampu melempar dan menangkap dengan kuat. Pada kemampuan motorik kelentukan 9 (53\%) anak dapat melempar dan menangkap bola dengan lentuk pada siklus II meningkat 17 (100\%) anak mampu melempar dan menangkap dengan lentuk. Sehingga kegiatan pembelajaran motorik dikatakan berhasil karena sudah mencapai indikator keberhasilan yang telah ditetapkan.

Saran berdasarkan hasil penelitian dan kesimpulan, peneliti mengemukakan beberapa saran sebagai berikut:

Bagi Guru mampu mengembangkan strategi pembelajaran yang diterapkan pada saat pembelajaran menjadi lebih kreatif dan inovatif melalui bermain lempar tangkap bola untuk meningkatkan motorik kasar. 
Bagi anak, melalui bermain lempar tangkap bola besar yang diterapkan pada kegiatan pembelajaran mampu membantu dalam meningkatkan kemampuan motorik kasar anak, sehingga kemampuan motorik kasar anak mengalami perkembangan sesuai dengan tahapan perkembangan.

Bagi peneliti, penelitian mengenai kemampuan motorik kasar menggunakan metode bermain lempar tangkap bola. Oleh karena itu motivasi bagi peneliti selanjutnya untuk menambah metode bermain yang lebih kreatif dan inovatif untuk meningkatkan dan mengembangkan kemampuan motorik kasar anak seperti dengan penambahan rintangan yang dilakukan secara bertahap dalam siklus sehingga kemampuan motorik kasar anak akan lebih meningkat.

\section{DAFTAR REFERENSI}

Acep Yoni. (2010). Menyusun Penelitian Tindakan Kelas. Yogyakarta: Familia. Andang Ismail. (2006). Education Games Menjadi Cerdas dan Ceria dengan Permainan Edukatif. Yogyakarta: Pilar Media.

Bachtiar. (2007). Permainan Besar II Bola Voli dan Bola Tangan. Jakarta: Universitas Terbuka.

Bambang Sujiono, dkk. (2008). Metode Pengembangan Fisik. Jakarta: Universitas Terbuka.

Depdiknas. (2009). Peraturan Menteri Pendidikan Nasional No. 58. Jakarta: Direktorat PAUD.

Dewi, Y. A. S. (2014). Analisis Implementasi Kurikulum Tingkat Satuan Pendidikan (KTSP) di Sekolah Dasar Negeri Pisang Candi 1 Malang. Modeling, 1(2), 94 109.

Dewi, Y. A. S. (2017). Metode Pembelajaran Guru Etnis Jawa- Madura Dalam Pengembangan Bahasa Siswa RA di Kabupaten Pasuruan. Seling, 3(2), 94-106.

Diana Mutiah. (2010). Psikologi Bermain Anak Usia Dini. Jakarta: Kencana.

Djumidar. (2005). Dasar-dasar Atletik. Jakarta: Universitas Terbuka.

Elizabeth B Hurlock. (1978). Perkembangan Anak. (Terjemahan: Med Meitasari Tjandrasa dan Muchicah Zarkasih). Jakarta: Erlangga.

Heri Rahyubi. (2012). Teori-Teori Belajar dan Aplikasi Pembelajaran Motorik. Bandung: Referens.

Martini Jamaris. (2006). Pekembangan dan Pengembangan Anak Usia Taman Kanak-kanak. Jakarta: Grasindo.

Mayke S. Tedjasaputra. (2001) Bermain, Mainan dan Permainan untuk Pendidikan Anak Usia Dini. Jakarta. 
M. Ramli. (2005). Pendampingan Perkembangan Anak Usia Dini. Jakarta: Depdiknas.

Santrock John. W. (2002). Life-Span Development. (Terjemahan: Juda Damanik dan Achmad Chusairi). Jakarta: Erlangga.

Samsudin. (2008). Pembelajaran Motorik di Taman Kanak-kanak. Jakarta: Prenada media grup.

Soegeng Santoso \& Anne Lies Ranti. (2002). Kesehatan dan Gizi. Jakarta: Depdikbud.

Sofia Hartati. (2005). Perkembangan Belajar Anak Usia Dini. Jakarta: Depdiknas.

Slamet Suyanto. (2005). Konsep Dasar Pendidikan Anak Usia Dini. Jakarta: Depdiknas.Suharsimi Arikunto. (2010). Manajemen Penelitian. Jakarta: Rineka Cipta.

Suharsimi Arikunto. (2010). Penelitian Tindakan. Yogyakarta: Aditya Media.

Sumantri, MS. (2005). Model Pengembangan Keterampilan Motorik Anak Usia Dini. Jakarta: Depdiknas.

Suwarsih Madya. (2011). Penelitian Tindakan (Action Research). Bandung: Alfabeta.

Tadkirotun Musfiroh. (2005). Bermain Sambil Belajar dan Mengasah Kecerdasan. Jakarta: Depdiknas.

Wina Sanjaya. (2009). Penelitian Tindakan Kelas. Jakarta: Kencana.

Yudha M Saputra. (2005). Pembelajaran Kooperatif untuk Meningkatkan Keterampilan Motorik Anak TK. Jakarta: Depdiknas. 